\title{
Alpha-Tocopherol and BAY 11-7082 Reduce Vascular Cell Adhesion Molecule in Human Aortic Endothelial Cells
}

\author{
Úrsula Catalán ${ }^{\mathrm{a}}$ Sara Fernández-Castillejo ${ }^{\mathrm{a}}$ Laia Pons $^{\mathrm{a}}$ Mercedes Heras $^{\mathrm{a}}$ \\ Gemma Aragonés $^{a}$ Neus Anglès ${ }^{b}$ Jose-Ramon Morelló ${ }^{b}$ Rosa Solà ${ }^{a}$ \\ a Unitat de Recerca en Lípids i Arteriosclerosi, CIBERDEM, Hospital Universitari Sant Joan, IISPV, \\ Facultat de Medicina i Ciències de la Salut, Universitat Rovira i Virgili, Reus, and b La Morella Nuts S.A., \\ Castellvell del Camp, Spain
}

\section{Key Words}

BAY 11-7082 - Alpha-tocopherol $\cdot$ Vascular cell adhesion

molecule-1 - Endothelial dysfunction - Human aortic

endothelial cells

\section{Abstract}

Background: In endothelial dysfunction, vascular cell adhesion molecule-1 (VCAM-1), E-selectin and intercellular adhesion molecule-1 (ICAM-1) expression (collectively termed cell adhesion molecules; (AMs) increase at sites of atherosclerosis and are stimulated by proinflammatory cytokines such as tumor necrosis factor- $\alpha$ (TNF- $\alpha$ ). Methods: We evaluated the effect of alpha-tocopherol (AT; 10-150 $\mu \mathrm{M}$ ) and BAY 11-7082 (BAY; 0.1 or $1 \mu \mathrm{M}$ ) on CAMs mRNA expression as well as their protein in soluble release form (sCAMs) in human aortic endothelial cells (HAECs) activated by TNF- $\alpha$ ( 1 or $10 \mathrm{ng} / \mathrm{ml}$ ). Also, we determined the extent of lymphocyte adhesion to activated HAECs. Results: BAY reduced VCAM-1, E-selectin and ICAM-1 mRNA expression by 30,30 and $10 \%$, respectively. Furthermore, protein reduction of sVCAM-1 by $70 \%$, sE-selectin by $51 \%$ and sICAM- 1 by $25 \%$ compared to HAECs stimulated by TNF- $\alpha$ was observed $(p<0.05)$. AT $(50,75$ and $150 \mu \mathrm{M}$ ) decreased VCAM-1 mRNA expression by $30 \%$ and sVCAM-1 protein by $33 \%$ compared to HAECs stimulated by
TNF- $\alpha(p<0.05)$. TNF- $\alpha$-activated HAEC adhesion to human Jurkat T lymphocytes was higher compared to nonactivated HAECs $(p<0.05)$. BAY $(2$ and $5 \mu M)$ reduced this lymphocyte adhesion $(p<0.05)$. Conclusion: BAY reduces all the CAMs studied as well as cell adhesion, while AT selectively inhibits VCAM-1; both induce endothelial dysfunction improvement.

Copyright $\odot 2012$ S. Karger AG, Basel

\section{Introduction}

Atherosclerosis can be considered the clinical endpoint of an inflammatory process and endothelial dysfunction. The binding of monocytes to the vascular endothelium is mediated by cross-linkage of cell adhesion molecules such as vascular cell adhesion molecule-1 (VCAM-1), E-selectin and/or intercellular adhesion molecule-1 (ICAM-1). The cell surface expression of these molecules is greatly increased in atherosclerotic lesions as a result of stimulation by proinflammatory cytokines such as tumor necrosis factor- $\alpha$ (TNF- $\alpha)$. This cytokine

Ú.C. and S.F.-C. contributed equally to the studies presented in this paper.

\section{KARGER}

Fax +4161306 1234

E-Mail karger@karger.ch

www.karger.com
(C) $2012 \mathrm{~S}$. Karger AG, Basel

$1018-1172 / 12 / 0494-0319 \$ 38.00 / 0$

Accessible online at:

www.karger.com/jvr
Dr. Rosa Solà

Facultat de Medicina i Ciències de la Salut, Universitat Rovira i Virgili

C/ Sant Llorenç 21

ES-43201 Reus, Tarragona (Spain)

Tel. +3497775 9369, E-Mail rosa.sola@urv.cat 
has been selected as a stressor molecule in assessing the underlying mechanisms because it induces release and surface expression of cell adhesion molecules (CAMs), all of which contribute to the inflammatory process and endothelial dysfunction [1-5]. Further to this, there is in vivo evidence of increased VCAM-1 production in animal models of inflammation [3].

Endothelial CAMs are known to be upregulated in atherosclerotic endothelium in an environment of circulating blood. They participate in leukocyte recruitment and, subsequently, in atherosclerosis progression and/or tissue damage [6].

E-selectin is an inducible endothelial cell surface glycoprotein of the selectin family of adhesion molecules. It mediates the binding of neutrophils, eosinophils, monocytes and Tlymphocytes to the endothelium [7].

VCAM-1 and ICAM-1 are members of the immunoglobulin superfamily of CAMs. They mediate lymphocyte adhesion to major elements of the aortic wall such as endothelial cells and vascular smooth muscle cells [8].

Induction of these three CAMs (VCAM, ICAM and E-selectin) by TNF- $\alpha$ is regulated at the level of gene transcription and requires the transcription nuclear factor$\kappa \mathrm{B}(\mathrm{NF}-\kappa \mathrm{B})$. Located in the cytoplasm of cells in an inactive form in close association with the inhibitor IкB- $\alpha$, NF- $\kappa \mathrm{B}$ binds to regulatory regions within promoter regions of the VCAM-1 gene $[9,10]$ via a process involving the phosphorylation and degradation of IкB- $\alpha$ [10-12].

In vitro studies indicate that VCAM-1, E-selectin and ICAM-1 are involved in the adhesion of eosinophils, monocytes and T lymphocytes via their cell surface [13]. Proteolytic cleavage of membrane-bound CAMs results in the release of their soluble forms - soluble CAMs (sCAMs), i.e. sVCAM-1, sE-selectin and sICAM-1 [6, 1416].

BAY 11-7082 [(E)3-[(4-methylphenyl)sulfonyl]-2-propenenitrile; BAY] is an anti-inflammatory and antioxidant molecule that selectively and nonreversibly inhibits the inducible phosphorylation of IkB- $\alpha$ in human pancreatic MIA PaCa-2 cancer cells [17] and endothelial cells [18]. As such, IkB- $\alpha$ avoids being degraded, resulting in a high level of cytosolic NF- $\mathrm{KB}$ sequestered by IkB, together with decreased transcription and surface expression of the adhesion molecules [17]. However, the effect of BAY on VCAM-1 mRNA expression and its soluble protein (sVCAM-1) on endothelial dysfunction induced by TNF- $\alpha$ in human aortic endothelial cells (HAECs) has not, as yet, been evaluated in detail.

Some natural compounds or extracts of certain foods have been described as reversing endothelial dysfunction
$[2,4,13,19,20]$. Prior to evaluating these functions in in vivo studies in animal and/or human subjects, in vitro cell models are developed to test the effects of these natural extracts (or compounds) based on the expression of cellular adhesion molecules in TNF- $\alpha$-stimulated cells. As such, in vitro models facilitate the study of cells under controlled conditions and can be used as tools to examine the effects of various natural or synthetic pharmacologically active compounds.

Dietary factors play significant roles in the etiology of atherosclerosis by influencing inflammatory and endothelial dysfunction processes associated with the development of this disease. Vitamin E, especially the main fat-soluble dietary antioxidant alpha-tocopherol (AT), is very effective in reducing the adhesion of monocytes to HAECs in vivo and in vitro [21].

Several studies have demonstrated that vitamin E decreases the cytokine-stimulated HAEC production of chemokines such as sVCAM-1, soluble intercellular cell adhesion molecule (sICAM-1) [3], interleukine (IL)- 6 and IL-8 [21] when stimulated with IL- $\beta$. Also, VCAM-1 mRNA expression levels are consistently elevated when incubated for between 6 and $24 \mathrm{~h}$ with TNF- $\alpha$ (10 ng/ml) and LPS $(10 \mu \mathrm{g} / \mathrm{ml})$ in human umbilical vein endothelial cells (HUVECs), with the levels remaining high under these conditions $[22,23]$. However, the effects of AT on endothelial dysfunction induced by TNF- $\alpha$ in HAECs are not well documented.

The aim of the present study was to test our hypothesis that, by modifying CAMs mRNA expression and sCAMs protein release, AT and BAY can improve endothelial dysfunction.

\section{Materials and Methods}

\section{Cell Culture}

HAECs (Cascade Biologics ${ }^{\mathrm{TM}}$, Portland, Oreg., USA) at the 5th passage were seeded on Nunclon ${ }^{\mathrm{TM}} \Delta$ surface 12 -well plates (for the mRNA assays), 24-well plates (for the protein assays) or 96 well plates (for the adhesion assays) at a density of approximately $12 \times 10^{3}$ of viable cells $/ \mathrm{ml}$. Cells were maintained for the first $24 \mathrm{~h}$ in complete cell culture medium (CM) composed of M-200 medium supplemented with $2 \%(\mathrm{v} / \mathrm{v})$ low serum growth supplement, $10 \mathrm{mg} / \mathrm{ml}$ gentamicin, $0.25 \mathrm{mg} / \mathrm{ml}$ amphotericin B (both purchased from Invitrogen, Paisley, UK), $100 \mathrm{U} / \mathrm{ml}$ penicillin and $100 \mathrm{mg} / \mathrm{ml}$ of streptomycin (both from Labclinics, Barcelona, Spain). The cells were grown to confluence at $37^{\circ} \mathrm{C}$ in a humidified incubator (Heracell 150; Madrid, Spain) with atmosphere containing $5 \% \mathrm{CO}_{2}$. The medium was replenished every 2 days with fresh CM. Viewed under an IMT2 microscope (Olympus, Barcelona, Spain), confluent monolayers displayed a typical monolayer phenotype of quiescent endothelial cells after 5 days 
in culture. All HAEC experiments were conducted at $37^{\circ} \mathrm{C}$ in a humidified atmosphere with $5 \% \mathrm{CO}_{2}$.

Jurkat T cell lymphocytes were purchased from DSMZ GmbH (Braunschweig, Germany). Jurkat T cells were cultured in RPMI medium 1640 + Glutamax-I (Gibco, Spain) supplemented with $20 \%$ heat-inactivated foetal bovine serum (FBS) (PAA, Labclinics,) for the first 2 days followed by $10 \% \mathrm{FBS}+100 \mathrm{U} / \mathrm{ml}$ penicillin and $100 \mathrm{mg} / \mathrm{ml}$ streptomycin for growth and the scheduled experiments. The Jurkat $\mathrm{T}$ cells were maintained until the cell-cell adhesion assays.

HAECs were preincubated with AT (10, 25, 50, 75 and $150 \mu \mathrm{M}$; Sigma Chemical Co., St. Louis, Mo, USA) and the respective vehicle control (absolute ethanol, Panreac, Madrid, Spain) for $6 \mathrm{~h}$, as recommended in the literature [23-27]. Then, as and when required, TNF- $\alpha$ (1 or $10 \mathrm{ng} / \mathrm{ml}$; Calbiochem, Darmstadt, Germany) and BAY (0.1 or $1 \mu \mathrm{M}$; Merck, Darmstadt, Germany) were added to the cell culture medium for $24 \mathrm{~h}$ to induce cell stimulation. Finally, except for the cell-cell adhesion assays, supernatants were collected and stored at $-20^{\circ} \mathrm{C}$ for batched measurements of the soluble forms of selected CAMs (sVCAM-1, sE-selectin and sICAM-1) and to measure the activity of the lactate dehydrogenase $(\mathrm{LDH})$ released. Cells were lysed and stored at $-80^{\circ} \mathrm{C}$ for batched TNF- $\alpha$ mRNA expression measurement. Fluorescent intensity was the method used to measure cell-cell adhesion.

\section{Cell Viability and Cytotoxicity}

Cell viability was assessed by morphology using phase-contrast microscopy and by trypan blue exclusion (Merck). Cell cytotoxicity was assessed with Cytotoxicity Detection Kit LDH (Roche Applied Science, Mannheim, Germany). Briefly, LDH enzyme is rapidly released into the cell culture supernatant when the plasma membrane is damaged. This results in a colorimetric reaction that can be measured at a wavelength of $492 \mathrm{~nm}$.

For these experiments, TNF- $\alpha$ treatment was considered the maximum stress condition for the cells. The activity of LDH released from cells was measured in cell-free supernatants collected at two key stages of the experiment: after 6-hour incubation with AT and after 24-hour incubation with TNF- $\alpha$ (alone or in the presence of BAY) at the various concentrations. Results are expressed as mean absorbance and SD (error bars) of LDH produced by the cells under each treatment condition.

Analysis of CAMs mRNA Expression by Real-Time

Quantitative Reverse Transcriptase Polymerase Chain

Reaction in HAECs Stimulated with TNF- $\alpha$

Dose- and time-course response experiments were performed by stimulating HAECs with TNF- $\alpha$. Once the appropriate experimental conditions were established (i.e. the capacity to measure minimal decreases in CAMs mRNA expression that may be induced by the compounds under investigation: AT and BAY), we opted for $10 \mathrm{ng} / \mathrm{ml}$ (for E-selectin and ICAM-1) or $1 \mathrm{ng} / \mathrm{ml}$ (for VCAM-1) of TNF-stimulation over a culture period of $24 \mathrm{~h}$, and BAY $1 \mu \mathrm{M}$ (for E-selectin and ICAM-1) or $0.1 \mu \mathrm{M}$ (for VCAM1).

Cells were lysed with nucleic acid purification lysis solution and total RNA was isolated from cells using the ABI PRISM 6100 Nucleic Acid PrepStation extraction system (Applied Biosystems, Foster City, Calif., USA) according to the manufacturer's protocol. Total RNA was quantified using Quant-it ${ }^{\mathrm{TM}}$ RNA Assay Kit and Qubit ${ }^{\mathrm{TM}}$ fluorometer (Invitrogen). Using the 2720 Thermal
Cycler (Applied Biosystems), $0.5 \mu \mathrm{g}$ of total RNA was reverse transcribed to cDNA at $42^{\circ} \mathrm{C}$ for 50 min using random hexamers, SuperScript II reverse transcriptase and RNAse Out (Invitrogen) according to the manufacturer's protocol. To determine the amount of VCAM-1, E-selectin and ICAM-1 mRNA, semiquantitative RT-PCR was performed using the ABI PRISM 7900 Detection System (Applied Biosystems) with the following profile: $95^{\circ} \mathrm{C}$ denaturing $(20 \mathrm{~s})$ with 40 cycles of extension at $95^{\circ} \mathrm{C}(1 \mathrm{~s})$ and $60^{\circ} \mathrm{C}(20 \mathrm{~s})$. Each sample was analyzed in triplicate and the cycle threshold $(\mathrm{Ct})$ was averaged from the values obtained in each reaction. VCAM-1, E-selectin and ICAM-1 mRNA expression results are reported as the increase ( $\mathrm{x}$-fold) using a $2^{-\Delta \Delta \mathrm{Ct}}$ mathematical method. The glyceraldehyde-3-phosphate dehydrogenase (GAPDH; Applied Biosystems) was used as a housekeeping gene to normalize the results. TNF- $\alpha$-activated endothelial cells were used as the calibrator in these experiments; its value was set at 1 and the other conditions were in relation to this reference value. Results are expressed as the mean and SD (error bars) of CAMs mRNA change relative to TNF- $\alpha$ alone.

\section{Measurement of $s$ CAMs Protein Secretion by HAECs \\ Stimulated with TNF- $\alpha$}

Dose- and time-course response experiments were performed by stimulating HAECs with TNF- $\alpha$. Once the appropriate experimental conditions were established, i.e. the capacity to measure minimal decreases in sCAMs protein secretion that may be induced by the compounds under investigation (in the present case AT and BAY; $1 \mu \mathrm{M}$ ), we opted for TNF- $\alpha$ at $10 \mathrm{ng} / \mathrm{ml}$ based on the concentrations used in previous reports with HUVECs $[23,26]$ or with HAECs $[1,19,20,25,27,28]$.

At the conclusion of the experiments, cells and supernatants were separated by centrifugation (Multifuge 3L-R; Madrid, Spain) at $1,500 \mathrm{~g}$ for $10 \mathrm{~min}$ at $4^{\circ} \mathrm{C}$. The cell pellet/debris was discarded and the cell-free supernatants used for sVCAM-1, sE-selectin, sICAM-1 measurements using enzyme-linked immunosorbent assays (ELISA) according to the manufacturer's protocol (for sVCAM-1 ELISA kit, Diaclone, Besançon, France; for sE-selectin and sICAM-1, Quantikine ELISA kits from R\&D Systems, Madrid, Spain).

All experimental data were compared to the outcomes in the TNF- $\alpha$-alone incubation, since this achieved the maximal secretion of sVCAM-1. A vehicle-alone control (vehicle for AT, absolute ethanol) was run in parallel and used as the control in this experiment. Results are expressed as the mean sCAMs protein secretion and SD (error bars).

\section{Calcein Labeling of Jurkat T Cells}

Calcein acetoxymethyl ester (calcein-AM, Molecular Probes, Eugene, Oreg., USA) was used to fluorescently label Jurkat T cells. Calcein is a nonfluorescent and lipophilic molecule which is cleaved by endogenous esterases and the resultant product's fluorescence can be measured at 485 and $530 \mathrm{~nm}$ (excitation and emission wavelengths, respectively).

The Jurkat $\mathrm{T}$ cells were fluorescently labeled by incubating cells $\left(25 \times 10^{6}\right.$ cells $\left./ \mathrm{ml}\right)$ with a final concentration of $5 \mu \mathrm{M}$ of calcein-AM for $30 \mathrm{~min}$ at $37^{\circ} \mathrm{C}$ and $5 \% \mathrm{CO}_{2}$. After calcein-AM loading, the cells were washed twice with RPMI-1640 medium supplemented with $10 \%$ FBS to remove excess dye. Cells were finally resuspended in CM at a density of $2.5 \times 10^{6}$ cells $/ \mathrm{ml}$. 
Cell-Cell Adhesion Assay

HAECs were seeded until confluent in black 96-well tissue culture plates. Following the appropriate culture with AT and BAY, calcein-AM-labeled Jurkat T cells were cocultured $(2.5 \times$ $10^{5}$ cells/well) with the HAEC monolayer for $1 \mathrm{~h}$ at $37^{\circ} \mathrm{C}$ in a humidified atmosphere with $5 \% \mathrm{CO}_{2}$. The nonadhered Jurkat T cells were removed from the HAEC monolayer by washing twice with CM. Fluorescence in each well of the culture plate was measured with the Synergy HT Fluorometer (BioTek Instruments, Alcobendas, Spain) $[29,30]$. Results are expressed as relative fluorescence units and SD (error bars).

\section{Statistical Analyses}

Data were expressed as the mean and SD (error bars) for sCAMs protein concentration and CAMs mRNA expression. Unless otherwise stated, all experiments were performed at least twice and each incubation condition was set up in triplicate. Analysis of variance (ANOVA) with Bonferroni's correction was used for multiple comparisons. A value of $\mathrm{p}<0.05$ was considered statistically significant.

A requisite for the analytical quality of the model was the control of several aspects involved in the cellular process and analytical performance of measurements. Thus, we evaluated the precision of the model by calculating the SD, SEM and the coefficients of variation (CV). All the results were analyzed with the Statistical Package for the Social Sciences (SPSS) software (version 19.0).

\section{Results}

\section{Cytotoxicity}

There was no evidence of HAEC cytotoxicity following exposure to $\operatorname{AT}(10,25,50,75$ and $150 \mu \mathrm{M})$ for $6 \mathrm{~h}$ (fig. 1a) nor TNF- $\alpha$ (10 ng/ml; fig. 1b) for the subsequent $24 \mathrm{~h}$. No cytotoxicity was observed, as assessed by LDH activity release, at the concentrations of BAY tested (1 $\mu \mathrm{M})$ under these experimental conditions.

\section{Effect of AT and BAY on CAMs mRNA Expression by HAECs Stimulated with TNF- $\alpha$}

Exposure of cells to TNF- $\alpha$ ( $1 \mathrm{ng} / \mathrm{ml}$ for VCAM- 1,10 $\mathrm{ng} / \mathrm{ml}$ for E-selectin and ICAM-1) for $24 \mathrm{~h}$ induced strong upregulation of CAMs mRNA expression (fig. 2). As shown in figure $2 \mathrm{a}, \mathrm{AT}$ (at 50, 75 and $150 \mu \mathrm{M}$ ) significantly reduced VCAM-1 mRNA expression in TNF- $\alpha$ stimulated HAECs by approximately $37 \%(\mathrm{p}<0.05)$. The intra-assay CV was $<20 \%$ and the inter-assay $\mathrm{CV}$ was $<21 \%$. Compared to TNF- $\alpha$ alone, BAY treatment $(0.1$ $\mu \mathrm{M})$ significantly blocked TNF- $\alpha$-induced VCAM-1 mRNA expression by approximately 25\% ( $\mathrm{p}<0.05$; fig. 2a). The intra- and inter-assay CVs were $<13 \%$.

There was a tendency towards reducing E-selectin mRNA expression by BAY and AT by approximately 40 and $25 \%$, respectively, but these reductions were not statistically significant (fig. 2b). ICAM-1 mRNA expression was decreased by AT and BAY by $25-40 \%$ and $13 \%$, respectively, compared to TNF- $\alpha$ stimulation. However, the decrease did not reach statistical significance (fig. 2c).

\section{Effects of AT and BAY on sCAMs Protein Secretion by}

HAECs Stimulated with TNF- $\alpha$

When cells were exposed to TNF- $\alpha(10 \mathrm{ng} / \mathrm{ml})$, sVCAM-1, sE-selectin and sICAM-1 increased significantly to $7.71(0.40), 0.33(0.08)$ and $13.31(0.76) \mathrm{ng} / \mathrm{ml}$, respectively ( $\mathrm{p}<0.05$; fig. 3 ). AT significantly reduced sVCAM-1 protein secretion by about $40 \%$ in the highest doses tested (50, 75 and $150 \mu \mathrm{M})$ compared to TNF- $\alpha$ alone $(10 \mathrm{ng} / \mathrm{ml} ; \mathrm{p}<0.05)$ (fig. 3a). No dose-response effect was observed. The inter- and intra-assay CVs were $<12 \%$. AT also reduced sE-selectin (between 5 and 29\%) and sICAM-1 (between 5 and 16\%) at all doses tested, but the decreases did not reach statistical significance.

BAY $(1 \mu \mathrm{M})$ reduced TNF- $\alpha(10 \mathrm{ng} / \mathrm{ml})$ effects on sVCAM-1, sE-selectin and sICAM-1 release by 53,50 and $26 \%$. Only the effects on sVCAM and sE-selectin were statistically significant $(\mathrm{p}<0.05$; fig. $3 \mathrm{a}-\mathrm{c})$. As shown in figure $3 \mathrm{~b}$ and $\mathrm{c}$, nonactivated HAECs did not appear to release sE-selectin (limit of detection $<0.125 \mathrm{ng} / \mathrm{ml}$ ) and sICAM-1 (limit of detection $<1.56 \mathrm{ng} / \mathrm{ml}$ ), but the nonactivated cells did express sVCAM-1 (2.12 ng/ml; fig. 3a). Treatment of HAECs with AT had no statistically significant reduction effect on the protein secretion of sE-selectin (between 5 and 29\% reduction) or sICAM-1 (between 6 and $16 \%$ reduction).

\section{Effect of AT and BAY on Lymphocyte Cell Adhesion to} HAECs

Qualitatively (fig. 4), there appeared to be a considerable number of Jurkat $\mathrm{T}$ cells adhering to TNF- $\alpha$-treated HAECs, while very few cells adhered to untreated HAECs. Adhesion to HAECs that had been incubated with BAY $(0.5,1,2$ and $5 \mu \mathrm{M})$ appeared to be greatly decreased. Adhesion to HAECs that had been preincubated with AT $(10,25,50,75$ and $150 \mu \mathrm{M})$ for $6 \mathrm{~h}$ appeared to decrease the adhesion of HAECs to Jurkat $\mathrm{T}$ cells at all concentrations tested (fig. 4).

The cell fluorescence images revealed that exposure of cells to TNF- $\alpha(10 \mathrm{ng} / \mathrm{ml})$ for $24 \mathrm{~h}$ induced strong adhesion between Jurkat T cells and HAECs (fig. 5). The effects of different concentrations of AT and BAY on TNF$\alpha$-induced cell surface adhesion molecule expression are depicted in figure 5. AT failed to modulate significantly the TNF- $\alpha$-induced cell surface expression of CAMs at 


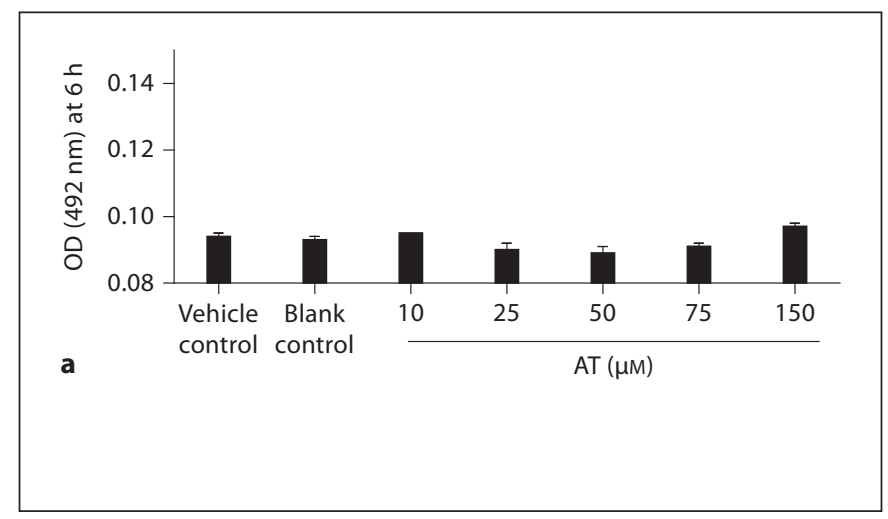

Fig. 1. Cytotoxicity from HAECs incubated with AT or BAY and stimulated with TNF- $\alpha$. a Activity of LDH released into the cellculture supernatants of HAECs following incubation with AT (10, 25, 50, 75 and $150 \mu \mathrm{M}$ ) for $6 \mathrm{~h}$. b Activity of LDH released into the cell-culture supernatants of HAECs following stimulation with TNF- $\alpha(10 \mathrm{ng} / \mathrm{ml})$ in the presence $(1 \mu \mathrm{M}$ for $24 \mathrm{~h})$ or absence of

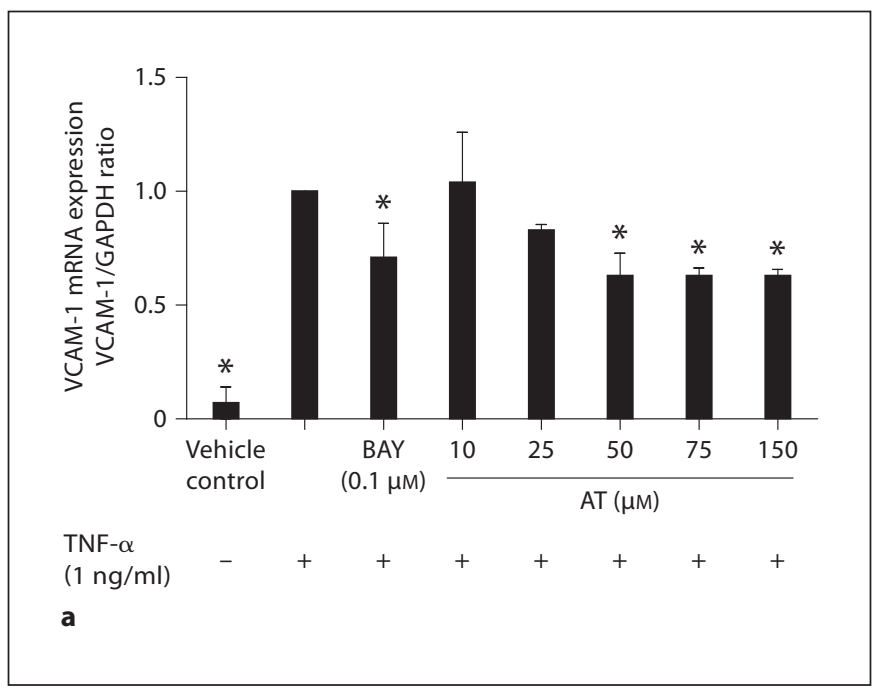

Fig. 2. Effect of AT and BAY on CAMs mRNA expression in HAECs stimulated by TNF- $\alpha$. a Effect of AT and BAY on VCAM1 mRNA expression. $\mathbf{b}$ Effect of AT and BAY on E-selectin mRNA expression. c Effect of AT and BAY on ICAM-1 mRNA expression. Results are the mean and the SD (error bars) of two independent experiments where each set of experimental conditions was run in triplicate. ${ }^{*} \mathrm{p}<0.05$ versus TNF- $\alpha$ alone.

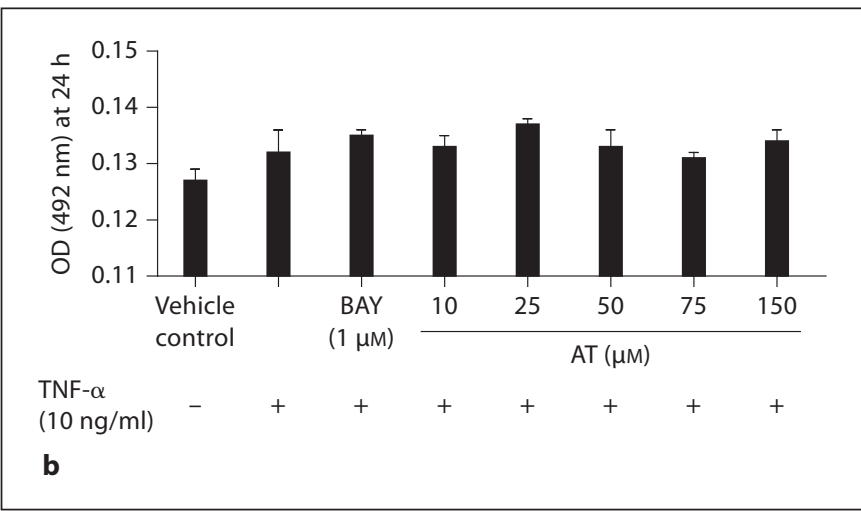

BAY. Vehicle control refers to cells incubated with AT vehicle (absolute ethanol). Blank control refers to cells incubated without ethanol, TNF- $\alpha$, BAY or AT. Results are the mean and the SD (error bars) of optical density (OD) from one representative experiment where each set of experimental conditions was run in triplicate.
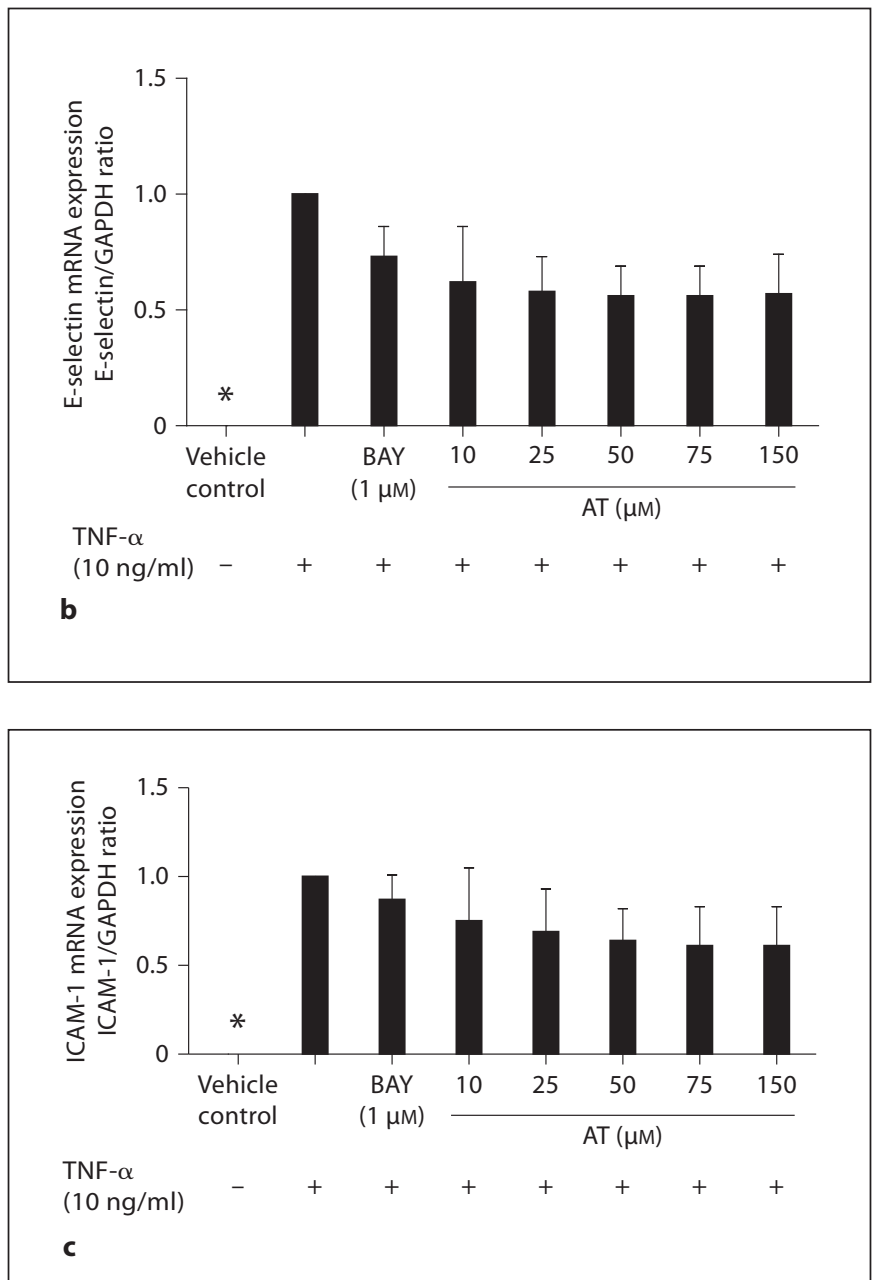

J Vasc Res 2012;49:319-328 


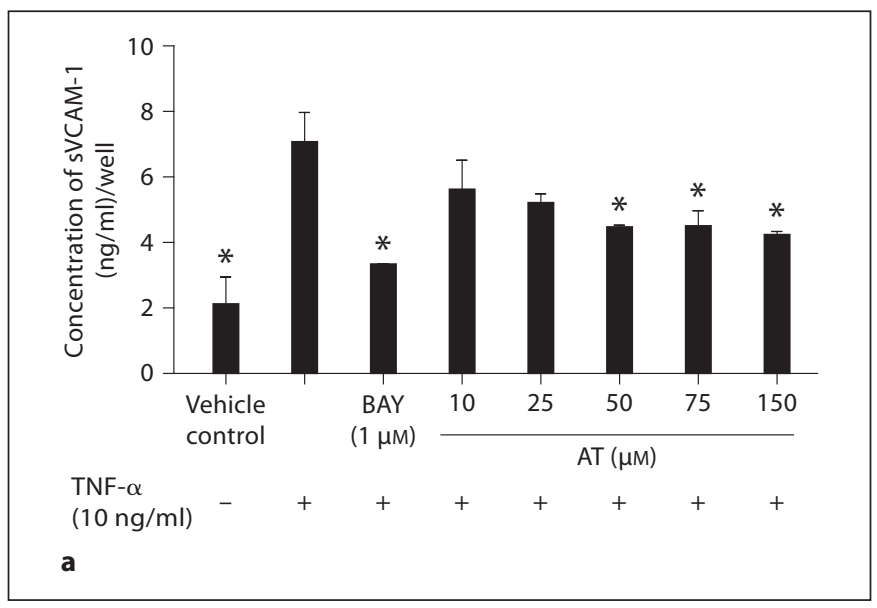

Fig. 3. Effect of AT and BAY on sCAMs protein secretion in HAECs stimulated by TNF- $\alpha$. a Effect of AT and BAY on sVCAM-1 protein release. b Effect of AT and BAY on sE-selectin protein release. $\mathbf{c}$ Effect of AT and BAY on sICAM-1 protein release. Results are the mean and the SD (error bars) of two independent experiments where each set of experimental conditions was run in triplicate. ${ }^{*} \mathrm{p}<0.05$ versus TNF- $\alpha$ alone.

any of the concentrations (a reduction of between 11 and $17 \%$; fig. 5). In contrast, when treated with $\operatorname{BAY}(0.1,1,2$ and $5 \mu \mathrm{M})$, the TNF- $\alpha$-induced cell surface expression of CAMs was notably reduced to 7, 13, 57 and $77 \%$, respectively; statistically significant reductions being observed only at 2 and $5 \mu \mathrm{M}(\mathrm{p}<0.05)$.

\section{Discussion}

Our results indicate that treatment with AT $(50,75$ and $150 \mu \mathrm{M})$ inhibits VCAM-1 mRNA and sVCAM-1 protein by between 36 and $40 \%$ in TNF- $\alpha$-stimulated HAECs $(\mathrm{p}<0.05)$. In contrast, when we analyzed the effects of AT on stimulated HAECs, we observed a nonsignificant decrease in E-selectin and ICAM-1 mRNA expression (40 and 25-40\%, respectively) and in sE-selectin and sICAM-1 protein release (5-29 and 5-16\%, respectively) compared to TNF- $\alpha$ alone $(10 \mathrm{ng} / \mathrm{ml})$. As such, AT appears to play a beneficial role in atherosclerosis by spe-
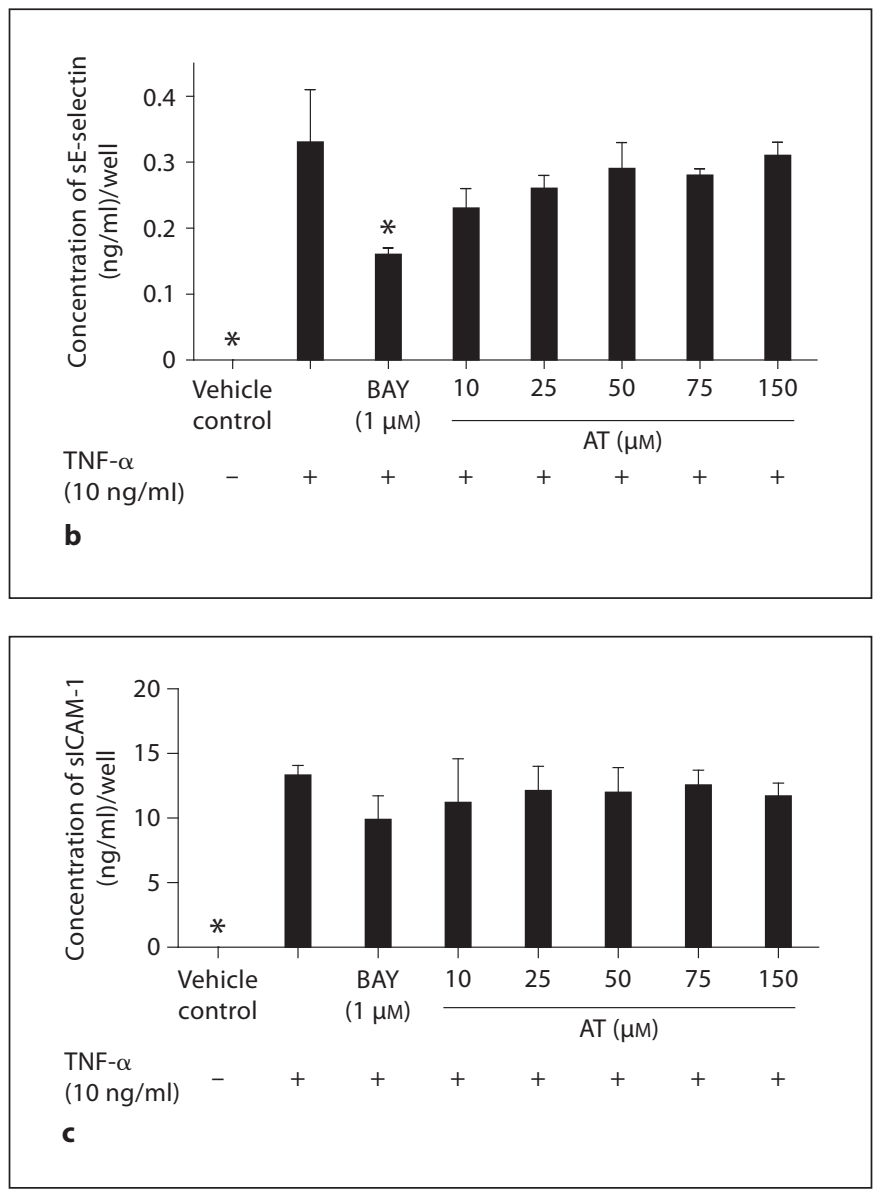

cifically reducing VCAM-1 but not the other CAMs studied, which were E-selectin and ICAM-1.

The optimum serum concentration of AT in humans is around $23.2 \mu \mathrm{M}$ [31], which is similar to the concentrations selected for our investigation. We also observed that, in TNF- $\alpha$-stimulated HAECs, BAY (at $0.1 \mu \mathrm{M}$ ) reduced VCAM-1 mRNA expression by $25 \%$ and sVCAM-1 protein release by $53 \%(\mathrm{p}<0.05)$. Similarly, BAY (at $1 \mu \mathrm{M})$ decreased E-selectin and ICAM-1 mRNA expression by 25 and $13 \%$, respectively, and sE-selectin and sICAM-1 protein release by 50 and $26 \%$, respectively; albeit these reductions were not statistically significant.

VCAM-1 is an important adhesion molecule that is upregulated during endothelial activation by various factors such as TNF- $\alpha$. Belonging to the immunoglobulin superfamily, it has adhesion molecule properties and acts as a ligand for activated leukocyte adhesion to endothelium [32].

Garton et al. [33] demonstrated in mice that VCAM-1 is released as a soluble form of the extracellular domain 


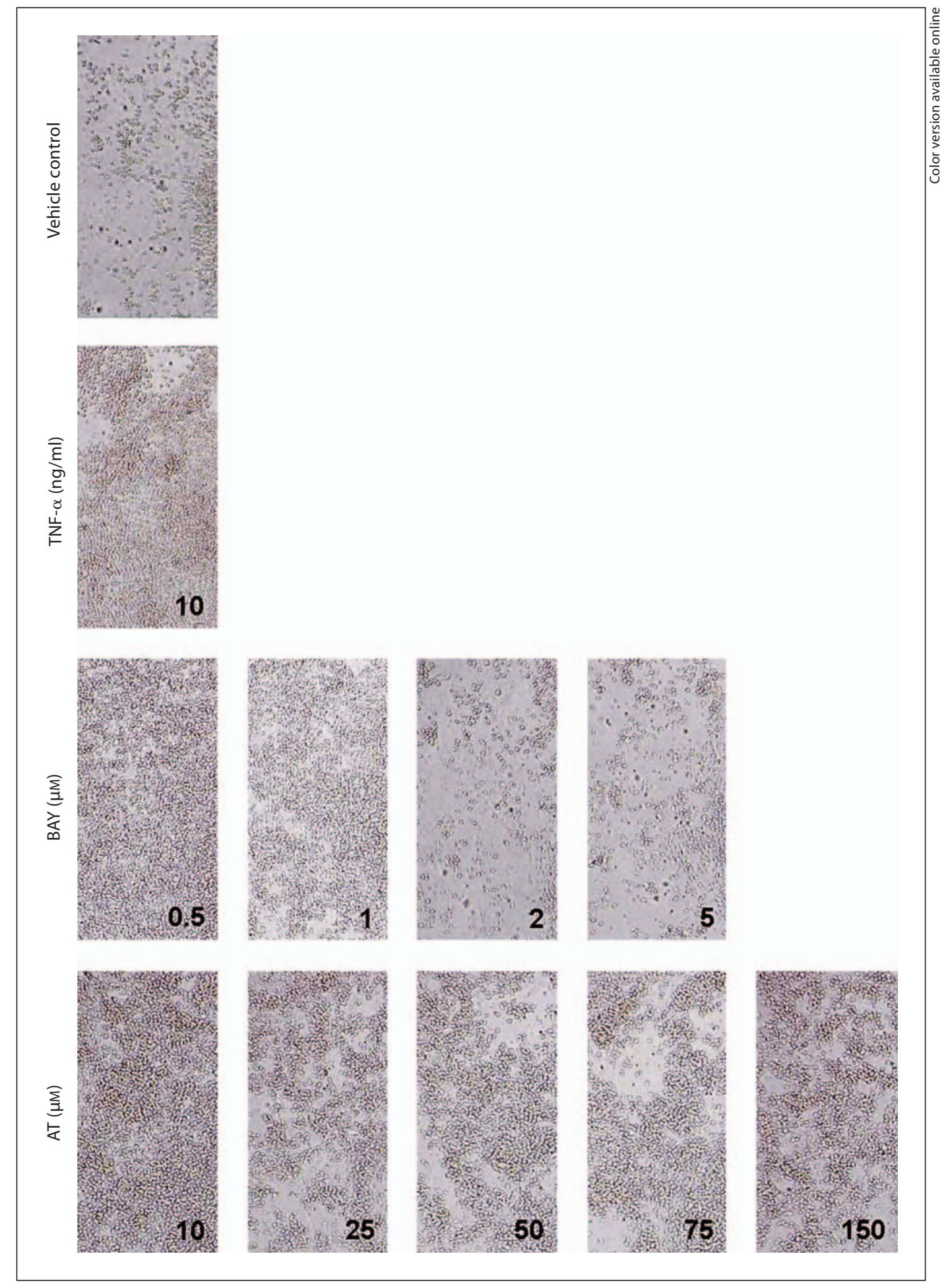

Fig. 4. Adhesion of Jurkat T cells to TNF- $\alpha$-treated HAEC images under microscope $(\times 4)$ - images of the experiments. Conditions used for this study were: vehicle control; TNF- $\alpha$ (10 ng/ml); BAY (0.5, 1, 2 and $5 \mu \mathrm{M})$; AT $(10,25,50,75$ and $150 \mu \mathrm{M})$. 


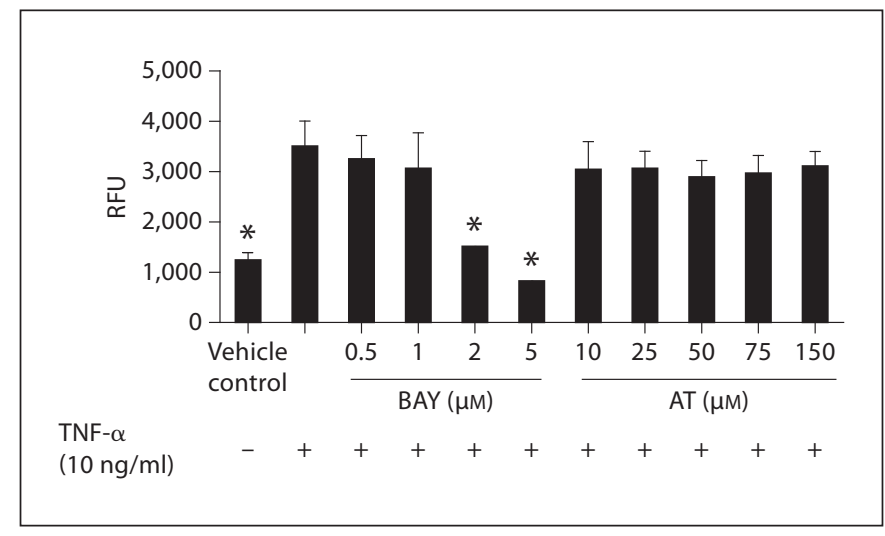

Fig. 5. Adhesion of Jurkat T cells to TNF- $\alpha$-treated HAECs. Effect of AT at all concentrations tested $(10,25,50,75$ and $150 \mu \mathrm{M})$ on cell-cell adhesion. Data are the mean and the SD (error bars) of relative fluorescence units (RFU) from two separate experiments run in octuplicate. ${ }^{*} \mathrm{p}<0.05$ versus TNF- $\alpha$ alone.

that is generated by TNF- $\alpha$-converting enzymes (TACE or ADAM 17) induced by phorbol 12-myristate 13-acetate. E-selectin is expressed in acute as well as in a chronically inflamed endothelium and induces rolling of circulating monocytes and/or leukocytes through this endothelium [34, 35].

ICAM-1 is also involved in atherosclerosis, presumably through the regulation of monocyte recruitment into atherosclerosis-prone areas. ICAM-1 expression is elevated in aortas that are predisposed to atherosclerosis and is regulated by proinflammatory stimuli such as that of TNF- $\alpha$.

E-selectin is involved in the leukocyte rolling on the endothelium, while VCAM-1 and ICAM-1 are involved in firm adhesion of leukocytes by binding to very late antigen- 4 and to leukocyte function antigen-1, respectively. This mechanism is in accordance with our findings in the functional experiments in which we observed no differences between leukocyte adhesion to activated HAECs in the presence or absence of AT.

With respect to the proteins of each individual sCAM, we observed different degrees of response to the same stimuli (TNF- $\alpha 10 \mathrm{ng} / \mathrm{ml}$ ) for each sCAM $(13.31 \mathrm{ng} / \mathrm{ml}$ for sICAM-1, $7.71 \mathrm{ng} / \mathrm{ml}$ for sVCAM-1, and $0.33 \mathrm{ng} / \mathrm{ml}$ for sE-selectin); the contribution of each one being different in the adhesion step of atherosclerosis. Deneva-Koycheva et al. [36] recently determined the reference ranges of sVCAM-1 (170.42-478.36 ng/ml), sE-selectin (9.15-65.19 $\mathrm{ng} / \mathrm{ml})$ and sICAM-1 (128.9-347.48 $\mathrm{ng} / \mathrm{ml})$ in the serum of healthy Bulgarians, with no gender-related differences in CAM concentrations $(\mathrm{p}>0.05)$. Human CAM serum concentrations are higher than those selected for the present study.

BAY, at 1 and $0.1 \mu \mathrm{M}$ in the present study, reduced both sVCAM-1 protein release and VCAM-1 mRNA expression $(\mathrm{p}<0.05)$. BAY $(1 \mu \mathrm{M})$ also reduced sE-selectin and sICAM-1 protein release as well as their mRNA expression, albeit without the reduction being statistically significant. At similar concentrations $(2,5$ or $12 \mu \mathrm{M})$ BAY has previously been described as inhibiting NF- $\kappa \mathrm{B}$ in different cell types [37-39]. Accordingly, in our study, protein release of the studied sCAMs was reduced as well as the adhesion between activated HAECs and Jurkat T cells by $\operatorname{BAY}(0.5,1,2$ and $5 \mu \mathrm{M})$; statistical significance being reached at BAY concentrations of 2 and $5 \mu \mathrm{M}(\mathrm{p}<0.05)$.

Based on previous reports on HUVECs $[23,26]$ and in HAECs $[1,19,20,25,28]$ in which the effects of compounds other than AT had been tested, we added TNF- $\alpha$ (at $10 \mathrm{ng} / \mathrm{ml}$ ) to the HAEC culture for $24 \mathrm{~h}$ to determine the sVCAM-1 protein release. A mean of $74.74 \mathrm{pg} / \mathrm{ml}$ (range: 64-84) serum TNF- $\alpha$ concentration was recorded in healthy children [40] and, as reported by Tomiyama et al. [41], control individuals have $1.7 \pm 0.5 \mathrm{pg} / \mathrm{ml} \mathrm{TNF}$ $\alpha$ in their circulation, while patients with obstructive sleep apnea have nearly $2 \mathrm{pg} / \mathrm{ml}$. Patients with systemic lupus erythematosus have $4.9 \pm 12.8 \mathrm{pg} / \mathrm{ml}$ and those with rheumatoid arthritis (an inflammatory disease) have $20 \pm 36.2 \mathrm{pg} / \mathrm{ml}[42,43]$. Hence, under inflammatory conditions, serum TNF- $\alpha$ levels can be high, approaching the TNF- $\alpha$ levels used in this study.

The production of adhesion molecules by endothelial cells has been shown to be regulated by redox-sensitive signal transduction and, thus, may be subjected to modulation by oxidants and antioxidants [44]. Since AT is a potent antioxidant, it would be reasonable to assume that the effects of this compound on reducing sVCAM-1 protein release in activated HAECs may be mainly due to its antioxidant properties in several endothelial cell types [21]. These outcomes are also observed at the mRNA expression level. Hence the results demonstrate that, apart from its antioxidant activities, AT can exert a modest inhibitory effect on adhesion molecule expression in vitro, and this suggests an improvement in endothelial dysfunction in HAECs.

It has been argued that HAECs or HUVECs may not adequately represent inflammatory changes in the microcirculation in tissues since these cells are isolated from a large artery or vein, respectively. The microvascular cell line HMEC-1 is reportedly one of the endothelial cell lines most similar to primary endothelium [21]. Results 
of sVCAM-1 in HMEC-1 cultures have shown wider variation than those from HUVEC experiments, and it is mainly for this reason that HUVECs have been used extensively in in vitro endothelium studies [45]. It is not clear, however, whether these differences render HMEC-1 a better or a poorer model of local inflammation than HUVECs. However, HUVECs provide more consistent results even if genetic differences between donors may result in wider variation in the expression of inflammation markers [45]. Further cell culture studies are required using HMEC-1 or human coronary artery endothelial cells to confirm the sVCAM-1 results that had been observed in HAECs [38].

\section{Conclusion}

Our results suggest that the effect of AT on mRNA expression was the cause of decreased rates of the cleaved soluble protein products of CAMs. However, the effect of BAY on decreasing CAMs mRNA expression was less than the decrease in the rates of their soluble protein products. The possible mechanism of action could be an inhibition of proteolytic cleavage to liberate the circulating form of sVCAM-1, or of alternative splicing. AT (at 50, 75 and 150 $\mu \mathrm{M})$, apart from having antioxidant and anti-inflammatory properties, also reduced VCAM-1 mRNA expression and sVCAM-1 protein release, while BAY (at $1 \mu \mathrm{M}$ ) reduced all CAMs studied (VCAM-1, E-selectin and ICAM1) and also reduced the overall adhesion between HAECs and Jurkat T cells, thus implying an improvement in endothelial dysfunction that had been induced by TNF- $\alpha$.

This in vitro model has its uses in assessing the potential beneficial effects of natural and manufactured compounds developed for the treatment of endothelium dysfunction and atherosclerosis.

\section{Acknowledgements}

This work was supported by the CENIT program of the Spanish Ministry of Industry and by a consortium of companies headed by La Morella Nuts (Castellvell del Camp, Tarragona, Spain), and with the collaboration of the following companies: KRAFT, BTSA (Biotecnologías Aplicadas) and Selecció Batallé. The funding bodies had no involvement in data interpretation or in the decision to submit the manuscript for publication.

\section{References}

1 Amberger A, Maczek C, Jurgens G, Michaelis D, Schett G, Trieb K, Eberl T, Jindal S, Xu Q, Wick G: Co-expression of ICAM-1, VCAM-1, ELAM-1 and Hsp60 in human arterial and venous endothelial cells in response to cytokines and oxidized low-density lipoproteins. Cell Stress Chaperones 1997; 2:94-103.

-2 Davis PA, Polagruto JA, Valacchi G, Phung A, Soucek K, Keen CL, Gershwin ME: Effect of apple extracts on NF- $\kappa \mathrm{B}$ activation in human umbilical vein endothelial cells. Exp Biol Med 2006;231:594-598.

- 3 Lee G, Na HJ, Namkoong S, Jeong Kwon H, Han S, Ha KS, Kwon YG, Lee H, Kim YM: 4-O-methylgallic acid down-regulates endothelial adhesion molecule expression by inhibiting NF- $\kappa B$-DNA-binding activity. Eur J Pharmacol 2006;551:143-151.

4 Wu D, Koga T, Martin KR, Meydani M: Effect of vitamin $\mathrm{E}$ on human aortic endothelial cell production of chemokines and adhesion to monocytes. Atherosclerosis 1999;147: 297-307.

5 Zhou Z, Liu Y, Miao AD, Wang SQ: Protocatechuic aldehyde suppresses TNF- $\alpha$-induced ICAM-1 and VCAM-1 expression in human umbilical vein endothelial cells. Eur J Pharmacol 2005;513:1-8.
-6 Dagia NM, Harii N, Meli AE, Sun X, Lewis CJ, Kohn LD, Goetz DJ: Phenyl methimazole inhibits TNF- $\alpha$-induced VCAM-1 expression in an IFN regulatory factor-1-dependent manner and reduces monocytic cell adhesion to endothelial cells. J Immunol 2004; 173:2041-2049.

7 Vannini N, Pfeffer U, Lorusso G, Noonan DM, Albini A: Endothelial cell aging and apoptosis in prevention and disease: E-selectin expression and modulation as a model. Curr Pharm Des 2008;14:221-225.

-8 Lawson C, Wolf S: ICAM-1 signaling in endothelial cells. Pharmacol Rep 2009;61:2232.

-9 Dieguez-Acuna FJ, Polk WW, Ellis ME, Simmonds PL, Kushleika JV, Woods JS: Nuclear factor $\kappa \mathrm{B}$ activity determines the sensitivity of kidney epithelial cells to apoptosis: implications for mercury-induced renal failure. Toxicol Sci 2004;82:114-123.

10 Pierce JW, Schoenleber R, Jesmok G, Best J, Moore SA, Collins T, Gerritsen ME: Novel inhibitors of cytokine-induced Ік $\mathrm{B} \alpha$ phosphorylation and endothelial cell adhesion molecule expression show anti-inflammatory effects in vivo. J Biol Chem 1997;272: 21096-21103.
11 Izban KF, Ergin M, Qin JZ, Martinez RL, Pooley RJ, Saeed S, Alkan S: Constitutive expression of NF- $\kappa \mathrm{B}$ is a characteristic feature of mycosis fungoides: implications for apoptosis resistance and pathogenesis. Hum Pathol 2000;31:1482-1490.

12 Spiecker M, Peng HB, Liao JK: Inhibition of endothelial vascular cell adhesion molecule- 1 expression by nitric oxide involves the induction and nuclear translocation of $\operatorname{I\kappa B} \alpha$. J Biol Chem 1997;272:30969-30974.

13 Martin KR, Wu D, Meydani M: The effect of carotenoids on the expression of cell surface adhesion molecules and binding of monocytes to human aortic endothelial cells. Atherosclerosis 2000;150:265-274.

14 Constans J, Conri C: Circulating markers of endothelial function in cardiovascular disease. Clin Chim Acta 2006;368:33-47.

-15 Just N, Tillie-Leblond I, Guery BP, Fourneau $\mathrm{C}$, Tonnel AB, Gosset P: Keratinocyte growth factor (KGF) decreases ICAM-1 and VCAM1 cell expression on bronchial epithelial cells. Clin Exp Immunol 2003;132:61-69.

16 Leeuwenberg JF, Smeets EF, Neefjes JJ, Shaffer MA, Cinek T, Jeunhomme TM, Ahern TJ, Buurman WA: E-selectin and intercellular adhesion molecule-1 are released by activated human endothelial cells in vitro. Immunology 1992;77:543-549. 
17 Kamthong PJ, Wu M: Inhibitor of nuclear factor $-\kappa \mathrm{B}$ induction by cAMP antagonizes interleukin-1-induced human macrophagecolony-stimulating-factor expression. Biochem J 2001;356:525-530.

18 Kopp E, Ghosh S: Inhibition of NF-кB by sodium salicylate and aspirin. Science 1994; 265:956-959.

19 Chen JW, Chen YH, Lin FY, Chen YL, Lin SJ: Ginkgo biloba extract inhibits tumor necrosis factor-alpha-induced reactive oxygen species generation, transcription factor activation, and cell adhesion molecule expression in human aortic endothelial cells. Arterioscler Thromb Vasc Biol 2003;23:15591566.

20 Chen YH, Lin SJ, Ku HH, Shiao MS, Lin FY, Chen JW, Chen YL: Salvianolic acid B attenuates VCAM-1 and ICAM-1 expression in TNF- $\alpha$-treated human aortic endothelial cells. J Cell Biochem 2001;82:512-521.

-21 Liu L, Zubik L, Collins FW, Marko M, Meydani M: The antiatherogenic potential of oat phenolic compounds. Atherosclerosis 2004; 175:39-49.

-22 Raab M, Daxecker H, Markovic S, Karimi A, Griesmacher A, Mueller MM: Variation of adhesion molecule expression on human umbilical vein endothelial cells upon multiple cytokine application. Clin Chim Acta 2002;321:11-16.

-23 Tribolo S, Lodi F, Connor C, Suri S, Wilson VG, Taylor MA, Needs PW, Kroon PA, Hughes DA: Comparative effects of quercetin and its predominant human metabolites on adhesion molecule expression in activated human vascular endothelial cells. Atherosclerosis 2008;197:50-56.

-24 Martin A, Wu D, Baur W, Meydani SN, Blumberg JB, Meydani M: Effect of vitamin E on human aortic endothelial cell responses to oxidative injury. Free Radic Biol Med 1996;21:505-511.

-25 Schleser S, Ringseis R, Eder K: Conjugated linoleic acids have no effect on TNF $\alpha$-induced adhesion molecule expression, U937 monocyte adhesion, and chemokine release in human aortic endothelial cells. Atherosclerosis 2006;186:337-344.

26 Shaw DI, Hall WL, Jeffs NR, Williams CM: Comparative effects of fatty acids on endothelial inflammatory gene expression. Eur J Nutr 2007;46:321-328.
Zhang WJ, Frei B: Albumin selectively inhibits TNF $\alpha$-induced expression of vascular cell adhesion molecule-1 in human aortic endothelial cells. Cardiovasc Res 2002;55:820 829.

28 Szekanecz Z, Shah MR, Pearce WH, Koch AE: Intercellular adhesion molecule-1 (ICAM-1) expression and soluble ICAM-1 (sICAM-1) production by cytokine-activated human aortic endothelial cells: a possible role for ICAM-1 and sICAM-1 in atherosclerotic aortic aneurysms. Clin Exp Immunol 1994;98:337-343.

29 Sen CK, Bagchi D: Regulation of inducible adhesion molecule expression in human endothelial cells by grape seed proanthocyanidin extract. Mol Cell Biochem 2001;216:1-7.

30 Roy S, Sen CK, Kobuchi H, Packer L: Antioxidant regulation of phorbol ester-induced adhesion of human Jurkat T-cells to endothelial cells. Free Radic Biol Med 1998;25: 229-241.

31 Gamez C, Artacho R, Ruiz-Lopez MD, Puerta A, Lopez MC: Nutritional status of vitamin $\mathrm{A}$ and $\mathrm{E}$ in institutionalized elderly people in Granada (Spain). J Nutr Sci Vitaminol (Tokyo) 1996;42:397-405.

32 Terry RW, Kwee L, Levine JF, Labow MA: Cytokine induction of an alternatively spliced murine vascular cell adhesion molecule (VCAM) mRNA encoding a glycosylphosphatidylinositol-anchored VCAM protein. Proc Natl Acad Sci USA 1993;90: 5919-5923.

33 Garton KJ, Gough PJ, Philalay J, Wille PT, Blobel CP, Whitehead RH, Dempsey PJ, Raines EW: Stimulated shedding of vascular cell adhesion molecule 1 (VCAM-1) is mediated by tumor necrosis factor- $\alpha$-converting enzyme (ADAM 17). J Biol Chem 2003;278: 37459-37464.

34 Galkina E, Ley K: Vascular adhesion molecules in atherosclerosis. Arterioscler Thromb Vasc Biol 2007;27:2292-2301.

35 Shapiro NI, Schuetz P, Yano K, Sorasaki M, Parikh SM, Jones AE, Trzeciak S, Ngo L, Aird WC: The association of endothelial cell signaling, severity of illness, and organ dysfunction in sepsis. Crit Care 2010;14:R182.

36 Deneva-Koycheva TI, Vladimirova-Kitova LG, Angelova EA, Tsvetkova TZ: Serum levels of siCAM-1, sVCAM-1, sE-selectin, sPselectin in healthy Bulgarian people. Folia Med (Plovdiv) 2011;53:22-28.
37 Bage T, Lindberg J, Lundeberg J, Modeer T, Yucel-Lindberg T: Signal pathways JNK and NF- $\kappa B$, identified by global gene expression profiling, are involved in regulation of TNF $\alpha$-induced mPGES-1 and COX-2 expression in gingival fibroblasts. BMC Genomics 2010;11:241.

-38 Calabro P, Cirillo P, Limongelli G, Maddaloni V, Riegler L, Palmieri R, Pacileo G, De Rosa S, Pacileo M, De Palma R, Golino P, Calabro R: Tissue factor Is induced by resistin in human coronary artery endothelial cells by the NF-kB-dependent pathway. J Vasc Res 2011;48:59-66.

39 Juliana C, Fernandes-Alnemri T, Wu J, Datta P, Solorzano L, Yu JW, Meng R, Quong AA, Latz E, Scott CP, Alnemri ES: Anti-inflammatory compounds parthenolide and Bay 11-7082 are direct inhibitors of the inflammasome. J Biol Chem 2010;285:9792-9802.

40 Lorini R, De Amici M, d'Annunzio G, Vitali L, Scaramuzza A: Low serum levels of tumor necrosis factor- $\alpha$ in insulin-dependent diabetic children. Horm Res 1995;43:206-209.

41 Tomiyama H, Okazaki R, Inoue D, Ochiai H, Shiina K, Takata Y, Hashimoto H, Yamashina A: Link between obstructive sleep apnea and increased bone resorption in men. Osteoporos Int 2008;19:1185-1192.

42 Bruni R, Serino FM, Galluzzo S, Coppolino G, Cacciapaglia F, Vadacca M, Nilo S, Terminio N, Afeltra A: Alexithymia and neuroendocrine-immune response in patients with autoimmune diseases: preliminary results on relationship between alexithymic construct and TNF- $\alpha$ levels. Ann NY Acad Sci 2006;1069:208-211.

43 Vadacca M, Bruni R, Cacciapaglia F, Serino F, Arcarese L, Buzzulini F, Coppolino G, Rigon A, Terminio N, Afeltra A: Alexithymia and immunoendocrine parameters in patients affected by systemic lupus erythematosus and rheumatoid arthritis (in Italian). Reumatismo 2008;60:50-56.

44 Li H, Cybulsky MI, Gimbrone MA Jr, Libby P: An atherogenic diet rapidly induces VCAM-1, a cytokine-regulatable mononuclear leukocyte adhesion molecule, in rabbit aortic endothelium. Arterioscler Thromb 1993;13:197-204.

45 Videm V, Albrigtsen M: Soluble ICAM-1 and VCAM-1 as markers of endothelial activation. Scand J Immunol 2008;67:523-531. 